\title{
The Collaboration of Social Entrepreneurship and Institution for Sustainable Regional Development Security
}

\author{
P. Eko Prasetyo*, Andryan Setyadharma, Nurjannah Rahayu Kistanti \\ Faculty of Economics, Universitas Negeri Semarang, Semarang, Indonesia \\ Email: *pekoprasetyo@mail.unnes.ac.id
}

How to cite this paper: Prasetyo, P. E., Setyadharma, A., \& Kistanti, N. R. (2021). The Collaboration of Social Entrepreneurship and Institution for Sustainable Regional Development Security. Open Journal of Business and Management, 9, 2566-2590. https://doi.org/10.4236/ojbm.2021.95141

Received: September 6, 2021

Accepted: September 25, 2021

Published: September 28, 2021

Copyright $\odot 2021$ by author(s) and Scientific Research Publishing Inc. This work is licensed under the Creative Commons Attribution International License (CC BY 4.0).

http://creativecommons.org/licenses/by/4.0/

\section{(c) (i) Open Access}

\begin{abstract}
Global prevention efforts, including mitigating the Covid-19 impact, require a more serious mechanism, such as maintaining sustainable regional development security. This research examines the role of social entrepreneurship collaboration with institutions in maintaining sustainable regional development security using empirical data and path analysis. To measure sustainability, sustainable entrepreneurship business opportunities are used as an aspect of sustainable regional development. The results show that the new model innovation of social entrepreneurship collaboration and institutional quality is an important mechanism capable of optimizing resource use, overcoming socio-economic problems and poverty, and increasing productivity. Furthermore, it is a value chain in promoting public policy implementation and mitigating sustainable regional development security. Since the new model innovation creates better social and economic justice values, it is the most important innovation element in the basic framework of social innovation sustainability theory.
\end{abstract}

\section{Keywords}

Collaboration, Institution, Social Entrepreneurship, Sustainable Regional Development

\section{Introduction}

Efforts to achieve sustainable development goals (SDGs) during the Covid-19 pandemic are challenging and require more critical strategies. However, social entrepreneurship and institutional collaboration help overcome these problems (OECD, 2017; Sanchez, 2018). In general, social entrepreneurship is perceived to be a basic tool for achieving sustainable development (Bansal, Garg, \& Sharma, 
2019). Economic and social entrepreneurship are essential in maintaining SDGs' security (Apostolopoulos et al., 2018; Volkmann et al., 2021; Guo et al., 2020). According to Chowdhury et al. (2019), institutions enhance the quality and quantity of entrepreneurship. This means that the functions of sustainable entrepreneurship and related institutions are widely studied research disciplines (Farny \& Binder, 2021; Sarango-Lalangui, Santos, \& Hormiga, 2018; Apostolopoulos et al., 2018; Chowdhury et al., 2019; Volkmann et al., 2021; Guo et al., 2020; Kim et al., 2020). Therefore, it is necessary to study social entrepreneurship collaboration with related institutions to create new entrepreneurial business opportunities that promote sustainable regional development. The main problem is how social entrepreneurship and institutional collaboration can be as security in sustainable regional development. The main purpose of this paper is to explain the importance of such collaboration.

Guo et al. (2020) emphasized the significance of conducting extensive research in sustainable and social entrepreneurship through a deeper examination of how institutional frameworks influence entrepreneurial activity in the Global South and North. This is because social entrepreneurs may solve problems through collaboration with stakeholders, leading to sustainable community innovation (Kim et al., 2020). Therefore, social entrepreneurship continues to receive much attention due to its potential as a source of economic and social equity and its role in promoting sustainable development to address social, poverty, economic and environmental problems (Roundy \& Bonnal, 2019; Khovrak, 2018; Starnawska \& Brzozowska, 2018; Anderson \& Gaddefors, 2016; Prasetyo, 2020a, 2020b).

Anderson and Ronteau (2017) reported that when entrepreneurship is a socio-economic process, it is vital to understand and influence social context aspects. Entrepreneurship is conducted through social relationships, interactions, and networking. Furthermore, general and social entrepreneurial activities stimulate sustainable development. However, the impact of general entrepreneurship is greater than social (Méndez-Picazo, Galindo-Martín, \& Castaño-Martínez, 2021). Anderson, Sarah, \& Sarah (2020) stated that entrepreneurship is broadly considered a socialized phenomenon and emphasized the need for further research on everyday entrepreneurs and their dominant challenges. This is in line with research that shows that social entrepreneurship, especially the significance of complementary support from related institutions, formal and informal social capital, should be studied (Guo et al., 2020).

According to Tvaronavičienè \& Lankauskienè (2012), institutional performance requires a shortcut from other aspects of sustainable development. Restrepo \& Clave (2019) discussed the role of important institutions for regional development. However, institutional factors still lack automatic effect like in endogenous growth. Research on social entrepreneurship has not emphasized the social relations that the community and the cultural environment operate. In general, social entrepreneurship is becoming increasingly important in regional 
development (Bencheva et al., 2017). Investments in social entrepreneurship are essential in providing employment, reducing poverty, and developing entrepreneurial initiatives that lead to sustainable regional development (Bencheva et al., 2017). Territorial collaboration offers a new way to address the widening gap between affluent cities and poor areas (Turok \& Alexis, 2020). Therefore, it is vital to examine social entrepreneurship collaboration with institutions as a safeguard for sustainable regional and global development. The novelty of this research is to examine the role of institutions as exogenous variables and collaborate with social entrepreneurship. This is meant to mitigate and promote new entrepreneurial business opportunities in sustainable regional socio-economic development.

Porter and Heppelemeann (2017) combined data from the index of social progress, institutional measures, and economic performance to examine institutional changes and economic performance related to social progress. The results showed a significant positive relationship between increased economic performance and social progress, which helped improve economic institutions and aspects of social progress, individual freedom, and social inclusion (Porter \& Heppelemann, 2017). Therefore, Porter's study forms a problem background for studying entrepreneurial social collaboration with institutions and other related determinants, such as social capital, standardization, productivity, inventions, new products, and technology, which promote entrepreneurial business opportunities and sustainable regional development security. This research implies that social entrepreneurship collaboration with institutions is an innovation model to create better, just, and prosperous socio-economic equity values sustainably. Suppose social entrepreneurship and institutional collaboration are successful, this innovative concept can be the most important theoretical basic element of sustainable social innovation.

Productive entrepreneurial and institutional collaborative capacities were used as a national and regional strategy in Colombia to overcome armed conflict, reduce violence and organize crime (Sanchez, 2018). Furthermore, social entrepreneurship and institutional development strategies in Croatia were used to increase social enterprise growth and institutional environment (OECD, 2017). However, the study of institutions and social entrepreneurship is very complex (Muñoz \& Kibler, 2017; Kimmitt \& Munoz, 2018). Muñoz \& Kibler (2017) examined the complexity problem of local institutions involved in social entrepreneurship. Very complex social problems embedded where people live were studied by Kimmitt \& Munoz (2018). However, no study has focused on examining the collaboration of social entrepreneurship and related institutions as mitigation in the achievement of regional and global sustainable development. This research explains the collaboration modeling and its mechanisms as a new model innovation for mitigating sustainable development.

Without reducing the meaning of other literature studies, the background of the urgency of the importance of this paper structurally is to focus more on the 
recommendations of the research results of Guo et al. (2020) and Anderson et al. (2020) and Porter \& Heppelemann (2017). Meanwhile, various previous studies still have gaps because they are more partial, so they contain many weaknesses as safeguards in regional development. Meanwhile, the results of Porter's (Porter \& Heppelemann, 2017) research which has tried to combine the data have not been maximized as expected by Guo et al. (2020) and Anderson et al. (2020). Furthermore, this paper is expected to make a major contribution to the repertoire of new economic institutional theory and social, as well as to serve as a good scientific reference in efforts to improve economic performance and social progress. Furthermore, the important implications of the results of this research are expected to be used as policy reinforcement in institutional decision making in promoting the improvement and security of sustainable development.

\section{Literature Review}

Theory suggests that entrepreneurial management practices should result in entrepreneurial activities (Wiklund, Eliaasson, \& Davidsson, 2002). The fundamental basis for building the basic concept of institutional collaboration and social entrepreneurship in this research is based on the assumption that entrepreneurial institutions and activities have a causal relationship (Baumol, 1990; Williamson, 2000; North, 2016; Chowdhury et al., 2019; Samadi, 2019). According to North $(1990,2003,2006)$, formal and informal institutions interact, though their impact can be influenced by informal institutions. Apart from being essential for entrepreneurship quality and quantity, institutions promote entrepreneurial activity (Sohel, 2018). There is a dynamic relationship between institutions and economic development (Chowdhury et al., 2019). In general, entrepreneurial activities contribute to economic growth, development, and prosperity (Chowdhury et al., 2019; Méndez-Picazo, Galindo-Martín, \& Castaño-Martínez, 2021).

The concept of entrepreneurship is well defined in economic theory by Schumpeter. Economist J.A. Schumpeter defined it as "creative activity" and introduced the concept of innovation as a key factor in entrepreneurship. Furthermore, entrepreneurship was considered a catalyst in driving the development process, meaning that entrepreneurial practices depend on the spirit of "creative destruction" (Schumpeter, 1942, 1949). Marshallian's entrepreneurship theory is generally accepted as the formation of successful and profitable business organizations. McClelland's entrepreneurship theory focuses on achieving the need for power, achievement, and affiliation as the most important factors for entrepreneurs (Royle \& Hall, 2012). However, Schumpeter's theory links entrepreneurship with business organizations and innovation or sustainable business development (Mehmood et al., 2019). According to Schumpeter, innovators are different from inventors. This is because inventors utilize and apply their inventions to create new combinations.

In Schumpeter's time, social entrepreneurship was not a core variable in the general entrepreneurial economic theory. Without neglecting the assertions of 
the McClelland and Marshallian theory, the basic concepts of entrepreneurship used in this research are based on Schumpeter's entrepreneurship theory (Schumpeter, 1949). Since Schumpeter's theory emphasizes the importance of creativity and innovation as determinants of success in entrepreneurship, it relates to the main problem and purpose of this research. McClelland's theory focuses more on internal factors, especially the need for achievement (N-Ach), hence used as a complement in the discussion. Furthermore, social entrepreneurship is an important developing aspect and a safeguard for industrialized countries' entrepreneurial activities (Hosseini \& Ziaaldini, 2019; Bansal, Garg, \& Sharma, 2019).

The basis of contemporary entrepreneurship theory focuses more on introducing business opportunities and the decision to take advantage of them (Acs et al., 2006). The prevailing entrepreneurship theory is often more linear in terms of an individual's ability to recognize business opportunities (Audretsch \& Keilbach, 2007). The previous research found that the institutional environment promoting productive entrepreneurship and human experimentation is the main determinant of economic growth (Prasetyo, 2020b). Therefore, the best place to start studying institutional theory is in the modification of instrumental rationality assumptions (North, 2016). Conceptually, the rationality and empiricism of the relationship between economic growth, factor input, institutions, and entrepreneurship were previously studied. The results supported the role of the entrepreneurial ecosystem in economic growth (Acs et al., 2018; Acs \& Lappi, 2021).

Steyart \& Hjorth (2006) stated that social entrepreneurship had been neglected in the entrepreneurial literature before the 2000s. In general, social entrepreneurship is a new concept that has attracted researchers and policymakers because it may benefit society and help maximize individual benefits (Tan, Williams, \& Tan, 2005). A recent literature study shows that the history of social entrepreneurship first appeared in Europe in the 1990s at the social-economic center, though its cooperative traditions were earlier encouraged by Italy (Zaki, 2018). Furthermore, the interest in studies regarding social entrepreneurship development is increasingly conducted (Nicholls, 2018; Bansal, Garg, \& Sharma, 2019; Bl'anda \& Urbančíková, 2020). According to Nicholls (2018), the term social entrepreneurship first appeared in the 1970s and attracted researchers, social activists, policymakers. It has become one of the most prominent innovative activities in civil society globally. Moreover, its development strategy activities have been widely studied in various disciplines integrated with sustainable regional development goals (Nicholls, 2018; Roundy \& Bonnal, 2019; Blagoycheva, 2019; de la Chaux \& Haugh, 2020; Bl'anda \& Urbančíková, 2020).

The results of literature studies show that the positive impact of entrepreneurship depends on various related determinants. Social entrepreneurship is the optimal mechanism for solving societal problems when public policy is preferred. Social problems are now the core of social entrepreneurship activities and drivers of individual and collective action (Farny, Kibler, \& Down, 2019; Pra- 
setyo, Setyadharma, \& Kistanit, 2020a, 2020b; Prasetyo \& Kistanti, 2020a, 2020b). Currently, the role and function of social entrepreneurship are the essential aspects of an inclusive entrepreneurship. It includes all aspects of activities that are socially beneficial. However, the theoretical studies on social entrepreneurship have not focused on it (Leoutre et al., 2020). There is no standard definition of social entrepreneurship. This concept is defined depending on the context and the phenomenon formed. Sustainable and social entrepreneurships are new research fields that are still developing (Volkmann et al., 2021; Prasetyo \& Kistanti, 2020a, 2020b). As a basic concept in this research, social entrepreneurship is interpreted to be a social-economic business model for the community whose main objective orientation is to achieve socio-economic equity and equitable social welfare.

Social entrepreneurship is important because it can help increase growth, achieve a stable, fair, and prosperous economy, and become an innovative market in various countries (Acs et al., 2018; Aparicio, Urbano, \& Gomez, 2018; Popov, Veretennikora, \& Kozinskaya, 2018; Sohel, 2018, Ogbo et al., 2019; Prasetyo \& Kistanti, 2020a; Deng et al., 2020). Apart from creating high expectations, it is considered a new approach to tackling poverty and social exclusion in developing countries (Seelos \& Mair, 2009). Social entrepreneurship is part of the social economy (Kazmi et al., 2016). Furthermore, social entrepreneurship and MSMEs can overcome the problem of social inequality and environmental sustainability and empirically reduce public spending, making it an important factor in the social economy's growth (Kraus et al., 2017; Prasetyo \& Kistanti, 2020a, 2020b). Furthermore, it contributes to regional economic development (Doh, 2020). The importance of social entrepreneurship in maintaining the locality or community and live safely is emphasized in regional economic development. Therefore, it should be included in economic mechanisms, such as carrying out business and making economic and financial policies (Jilenga, 2017). Furthermore, human and social capitals are important factors in promoting social entrepreneurship's success (Jilenga, 2017; Prasetyo, 2020b).

The modern theory of entrepreneurship is closely related to institutions (North, 1990). Theoretically and practically, social entrepreneurship is a growing economic activity and academic interest (Santos, 2010). The entrepreneurial function is a vital component in output and productivity growth (Baumol, 1993). The greater the speed of new technology deployment in business, the greater its contribution to productivity (Baumol, 1993). This means that entrepreneurship's role is important in the daily business environment and enhances a modern and productive world economy (Prasetyo, 2020a, 2020b). Social entrepreneurship has always been a concept often contested in academic discourse and practice (Abhi, 2017; Callavo, 2018). However, there is no statistical difference in the parameters for economic and social entrepreneurship (Abhi, 2017). The concept is often associated with social entrepreneurs and social enterprises (Prasetyo \& Kistanti, 2020a, 2020b).

Entrepreneurship has many positive impacts on economic growth, welfare, 
including social and environmental welfare, and unemployment reduction (Farouq \& Dadwal, 2019; Neumann, 2021; Prasetyo \& Kistanti, 2020a; Prasetyo, 2020a, 2020b). Although the social entrepreneurship impact can be static and dynamic, it should be more transformative (Beckmann, 2012). In many people, social entrepreneurship shows "new hopes for sustainable development" (Seelos \& Mair, 2009). It is also very important to open economic growth and inclusion for developing countries, such as Pakistan (Kazmi et al., 2016). In general, social entrepreneurship is a future business with social responsibility, prioritizing social missions before making profits (Pongracz, 2020). As a hybrid business model, it can bring innovation, create sustainable employment, reduce unemployment, promote regional development, and improve residents' life quality (Pongracz, 2020). According to Leoutre et al. (2020), countries with higher levels of traditional entrepreneurial activity often have higher social entrepreneurship levels. This means that social entrepreneurship has many benefits but still requires an institutional environment with the right quality for efficiency (Popov, Veretennikora, \& Kozinskaya, 2018).

Institutional theory is a theoretical lens used for entrepreneurship research (Bruton, Alhstrom, \& Li, 2010). The institutions help reduce uncertainty in the world (North, 2003). Moreover, they are the rules of behavior in a more formal society or boundaries, where humans have new ways of shaping their interactions (North, 2003). Economic institutions' role is considered to be the fundamental cause of economic growth (Acemoglu \& Robinson, 2008). Furthermore, formal and informal institutional factors are contextual components included in social progress and promote entrepreneurial opportunities to achieve higher economic growth levels (Aparicio, Turroo, \& Noguera, 2020). This means that the economic institution's contribution to development has far exceeded the availability of natural resources, the supply of other production factors, and technological advances (Acemoglu \& Robinson, 2008; Prasetyo \& Dzaki, 2020; Prasetyo, Setyadharma, \& Kistanti, 2019). A recent literature study showed that the configuration of institutional conditions and social capital has led to a high prevalence rate of various social entrepreneurship activities in a country (Deng et al., 2020). Furthermore, institutional theory related to social entrepreneurship positively contributes to the development of socially-oriented activities and new institutional theories (Popov, Veretennikora, \& Kozinskaya, 2018).

Recent developments in institutional theory offer new insights into how organizations run them. However, organizations still face institutional complexity whenever they confront inappropriate prescriptions from various institutional logics (Agrawal \& Hockerts, 2016; Lee et al., 2020). Furthermore, basic institutional theory in social entrepreneurship research provides useful insights into the organizational formation, vision, mission, identity, culture, processes, and memory (Agrawal \& Hockerts, 2016; Acs \& Lappi, 2021). Previous research indicates that formal and informal institutions' combined institutional configuration offers more explanatory power than examining their individual effects 
(Stephan, Uhlaner, \& Stride, 2015). This research emphasizes the importance of complementary support from formal and informal social capital institutions (Stephan, Uhlaner, \& Stride, 2015). Social capital helps reduce transaction costs by activating access to other resources through complementary and collaborative cooperation (Prasetyo, Setyadharma, \& Kistanti, 2020b).

The aspects of sustainable development have been defined in various ways but still include economic, environmental and social (Jovovic et al., 2017). When associated with the SDGs goals, sustainable entrepreneurship in this research is interpreted as new discovery efforts, the creation, and exploitation of new entrepreneurial business opportunities, or new model innovations through social entrepreneurship collaboration with related institutions to create goods and services, remaining friendly to environmental quality through economic, social, psychological and cultural approaches. This means that the word security and sustainability conceptions might be problem mitigation and efforts to achieve global world goals in a contemporary way (Tvaronavičienè \& Lankauskiené, 2012). This is because the basic concepts of the fundamental theory developed in discussing both of them are negligent. The concept has important implications for practitioners focusing on spurring the entrepreneurial ecosystem and social entrepreneurship in sustainable development (Roundy \& Bonnal, 2019).

\section{Research Methods}

This is a descriptive research with an explanatory design and mixed-method based on triangulation and complementary designs. In-depth qualitative and quantitative analyses are used according to empirical data triangulation and complementary designs, respectively. Triangulation and complementary design methods are used to obtain novelty inventions that are scientifically more convincing. These mixed-methods are chosen because they are complementary and integrated and can further improve the quality of article reporting (Fàbregues et al., 2020). Furthermore, empirical data collection is conducted using scientific methods in a rigorous, objective, and disciplined manner. Additionally, social entrepreneurship and institutional variables are arranged systematically with informants based on data in the field, documents, and in-depth structured interviews. The sample respondents interviewed should not be biased. Therefore, sample respondents need to be free from various political level interventions. Quantitative variable data is obtained using the Gini index value (IGX) measurement scale with the following formulation (Prasetyo \& Kistanti, 2020a, 2020b; Prasetyo, Setyadharma, \& Kistanti, 2019).

$$
\mathrm{IGx}=1-\sum_{i=1}^{n} f_{i}\left(Y_{i}-Y_{i-1}\right)
$$

The study used the three-step research methodology rigorously. First, the reliability and validity tests were carried out objectively on the qualitative and quantitative empirical data. The main purpose of testing the reliability and va- 
lidity in this research is to make sure that the questionnaire compiled as an instrument in data collection is really good, reliable, relevant and valid, so that the instrument can be used to measure what should be measured. This instrument has previously been tested and discussed several times with different reviewers, so that reliability as a measurement process can be considered consistent, precise and reliable. Meanwhile, based on the Karl Pearson Product Moment correlation test, the instrument has also been declared valid.

The operational definition of regional sustainable development security is a categorical independent variable measured in the aspects of entrepreneurial business opportunities in each experimental regression model. Based on the statistical test results, the quantitative data is conducted on an econometric model experimental test with linear regression analysis techniques in form of reconstructions and product-moment correlation and causality test. This occurs in the second step to determine the best model that suits the research purposes. As the basis for the analysis, the Karl Pearson Product Moment correlation and the statistical causality tests were assessed through SPSS. The results showed that there is a positive and significant relationship between social entrepreneurship and institutions. Also, there is a causal relationship between these two variables. In the third step, the best model that fulfills the requirements of path analysis structure equation is chosen and further interpretations conducted both descriptively and comparatively. To understand quantitative analysis with the path analysis model, it is necessary to compile the econometric functional equation form into a path analysis structure equation model.

$$
\begin{aligned}
\mathrm{Pdt}_{i}=\rho \mathrm{Pdt}_{i} \cdot \mathrm{SC}_{0}+\rho \mathrm{Pdt}_{i} \cdot \mathrm{SE}_{1}+\rho \mathrm{Pdt}_{i} \cdot \mathrm{Ist}_{2}+\varepsilon_{1} \\
\mathrm{EBO}_{i}=\rho \mathrm{EBO}_{i} \cdot \mathrm{SE}_{1}+\rho \mathrm{EBO}_{i} \cdot \mathrm{Ist}_{2}+\rho \mathrm{EBO}_{i} \cdot \mathrm{Pdt}_{3}+\varepsilon_{2} \\
\mathrm{EBO}_{i}=\rho \mathrm{EBO}_{i} \cdot \mathrm{SC}_{0}+\rho \mathrm{EBO}_{i} \cdot \mathrm{SE}_{1}+\rho \mathrm{EBO}_{i} \cdot \mathrm{Ist}_{2}+\rho \mathrm{EBO}_{i} \cdot \mathrm{Pdt}_{3}+\varepsilon_{3} \\
\mathrm{EBO}_{i}=\rho \mathrm{EBO}_{i} \cdot \mathrm{HC}_{0}+\rho \mathrm{EBO}_{i} \cdot \mathrm{SE}_{1}+\rho \mathrm{EBO}_{i} \cdot \mathrm{Ist}_{2}+\rho \mathrm{EBO}_{i} \cdot \mathrm{Pdt}_{3}+\varepsilon_{4} \\
\mathrm{EBO}_{i}=\rho \mathrm{EBO}_{i} \cdot \mathrm{SE}_{1}+\rho \mathrm{EBO}_{i} \cdot \mathrm{Ist}_{2}+\rho \mathrm{EBO}_{i} \cdot \mathrm{Std}_{5}+\varepsilon_{5} \\
\mathrm{EBO}_{i}=\rho \mathrm{EBO}_{i} \cdot \mathrm{SE}_{1}+\rho \mathrm{EBO}_{i} \cdot \mathrm{Ist}_{2}+\rho \mathrm{EBO}_{i} \cdot \mathrm{Cmr}_{6}+\varepsilon_{6} \\
\mathrm{EBO}_{i}=\rho \mathrm{EBO}_{i} \cdot \mathrm{SE}_{1}+\rho \mathrm{EBO}_{i} \cdot \mathrm{Ist}_{2}+\rho \mathrm{EBO}_{i} \cdot \mathrm{Inv}_{7}+\varepsilon_{7} \\
\mathrm{EBO}_{i}=\rho \mathrm{EBO}_{i} \cdot \mathrm{SE}_{1}+\rho \mathrm{EBO}_{i} \cdot \mathrm{Ist}_{2}+\rho \mathrm{EBO}_{i} \cdot \mathrm{NP}_{8}+\varepsilon_{8} \\
\mathrm{EBO}_{i}=\rho \mathrm{EBO}_{i} \cdot \mathrm{SE}_{1}+\rho \mathrm{EBO}_{i} \cdot \mathrm{Ist}_{2}+\rho \mathrm{EBO}_{i} \cdot \mathrm{Tnl}_{9}+\varepsilon_{9}
\end{aligned}
$$

This research model examines the effects and relationships between variables, including social entrepreneurship (SE), institution (Ist), productivity (Pdt), social capital (SC), human capital (HC), standardization (Std), commercialization (Cmr), the invention (Inv), new product (NP), and technology ( Tnl) empirically, to entrepreneurial business opportunities $\left(\mathrm{EBO}_{i}\right)$ as an operational measurement dimension for the sustainable regional development security. Particularly, this research examines how the collaboration between social entrepreneurship (SE) and institutional (Ist) factors provide the most optimal contribution as a "value chain" that drives entrepreneurial business opportunities and sustainable re- 
gional development. Furthermore, the research examines the mechanisms, integration, complementary, and collaboration between social entrepreneurship and institutions in promoting the process of discovering new opportunities for sustainable entrepreneurship. Since social entrepreneurship should be institutionalized for holistic sustainability, this new innovation model needs to be tested as the best sustainability innovation model.

The conception of global sustainable development security achievement can be implemented to analyze maximum regional development endurance. This is because the meaning transfers of all concepts from global to regional sustainable aspects are methodologically more concrete and simpler. Therefore, this research presents a problem that relates to sustainable development at the regional (micro and meso) level through a combination of the social, economic, cultural, and psychological theories reflecting global (macro and international) sustainability. This research forms the basis for future discussion as a basic theoretical approach, apart from helping strengthen and understand sustainable regional economic development. Additionally, some strengthening basic theoretical approaches are new and old institutional, community development, social network, and business theories. Essentially, the business theory includes product and profit cycles, product development, business management, and portfolios. The basic theoretical approach is conducted and chosen selectively. It should be appropriate and related to the variables studied in this research.

\section{Results and Discussion}

In Schumpeter's $(1942,1949)$ theory, economic development innovation is a structural change process supported by innovation with new combinations. In this research, the collaboration between social entrepreneurship and institutions is assumed to be an innovation or a new combination. Therefore, sustainable regional economic development is a process of structural change supporting innovation with collaboration between social entrepreneurship and related institutions. The sustainability and security of regional economic development are caused by opportunity activities that create new products and markets through collaboration. This is because social entrepreneurship is included in social economics as a new discipline and a multidisciplinary field that examines relations in economic, anthropological, political-scientific, psychological, and other sociological theories (Pongracz, 2020).

Table 1 shows the empirical data from path analysis regression in this study. Research activities on social entrepreneurship have reached disciplines that attract experts in regional studies and economic geography (Saebi, Foss, \& Linder, 2019; Kibler \& Munoz, 2020). This research used various aspects of the scientific discipline or the basic theory that accompanies it. As a basis for strengthening the arguments, sociological and social-economic theories are used to expand new social entrepreneurship perspectives that are more sensitive to place (Kibler \& Munoz, 2020). 
Table 1. The results of main model regression for path analysis.

\begin{tabular}{|c|c|c|c|c|c|c|c|c|}
\hline & \multirow{2}{*}{ Model } & \multicolumn{2}{|c|}{ Unstandardized Coefficients } & \multirow{2}{*}{$\begin{array}{c}\begin{array}{c}\text { Standardized } \\
\text { Coefficients }\end{array} \\
\text { Beta }\end{array}$} & \multirow{2}{*}{ t-stc } & \multirow{2}{*}{ Sig. } & \multicolumn{2}{|c|}{ Collinearity Statistics } \\
\hline & & B & Std. Error & & & & Tolerance & VIF \\
\hline \multirow{4}{*}{ 1) } & (Constant) & -0.322 & 0.035 & & -9.089 & 0.000 & & \\
\hline & Social Capital (SC) & -0.197 & 0.107 & -0.152 & -1.844 & 0.068 & 0.264 & 3.784 \\
\hline & Social Entrepreneurship (SE) & 0.475 & 0.095 & 0.388 & 5.005 & 0.000 & 0.299 & 3.347 \\
\hline & Institutional (Ist) & 1.020 & 0.091 & 0.701 & 11.175 & 0.000 & 0.457 & 2.186 \\
\hline \multirow{4}{*}{ 2) } & (Constant) & -0.099 & 0.039 & & -2.512 & 0.013 & & \\
\hline & Social Entrepreneurship (SE) & 0.389 & 0.068 & 0.358 & 5.763 & 0.000 & 0.447 & 2.236 \\
\hline & Institutional (Ist) & 0.587 & 0.104 & 0.454 & 5.623 & 0.000 & 0.265 & 3.775 \\
\hline & Productivity (Pdt) & 0.144 & 0.078 & 0.162 & 1.847 & 0.067 & 0.224 & 4.468 \\
\hline
\end{tabular}

1) Model-1 Dependent Variable: Productivity (Pdt); 2) Model-2 Dependent Variable: Entrepreneurial Business Opportunities (EBO).

Table 1 and model- 1 show that partially the role of institutions has the largest positive and significant contribution to productivity, specifically $70.10 \%$. Social entrepreneurship's role has the second-largest positive and significant contribution, amounting to $38.80 \%$ of productivity. Social capital factors have the smallest contribution to productivity. In this research, the social capital and entrepreneurship are a derivative of the human capital. The previous research shows that human capital is the main factor that drives productivity and economic growth (Prasetyo, 2020a, 2019b). This is in line with previous research showing that an entrepreneur needs to focus on investing in human capital to increase productivity (Hatak \& Zhou, 2021). Moreover, Hatak \& Zhou recommended research on the interaction between various human resources, including health, to support entrepreneurial success.

In model-2, institutions and social entrepreneurship's role have the first and second-largest positive and significant contributions to entrepreneurial business opportunities. The role of the productivity factor makes the third contribution to entrepreneurial business opportunities. Consequently, institutions and social entrepreneurship's role is the main factor that promotes and fosters regional sustainable entrepreneurial business opportunities. These results linearly strengthen the previous research, which established that institutional factors promote entrepreneurial opportunities to achieve higher economic growth levels (Prasetyo \& Dzaki, 2020; Prasetyo \& Kistanti, 2020a). Model-2 shows that institutional factors and entrepreneurship's contribution to business opportunities is $45.40 \%$ and $35.80 \%$, respectively. The productivity factor only provides a positive and significant contribution of $16.20 \%$.

Based on the results in Table 1 as described in Figure 1, the contribution path of social entrepreneurship and institution roles, both directly, indirectly, and totally towards efforts to achieve business opportunities as a measurement aspect for security in sustainable regional development is clear. Entrepreneurship and 


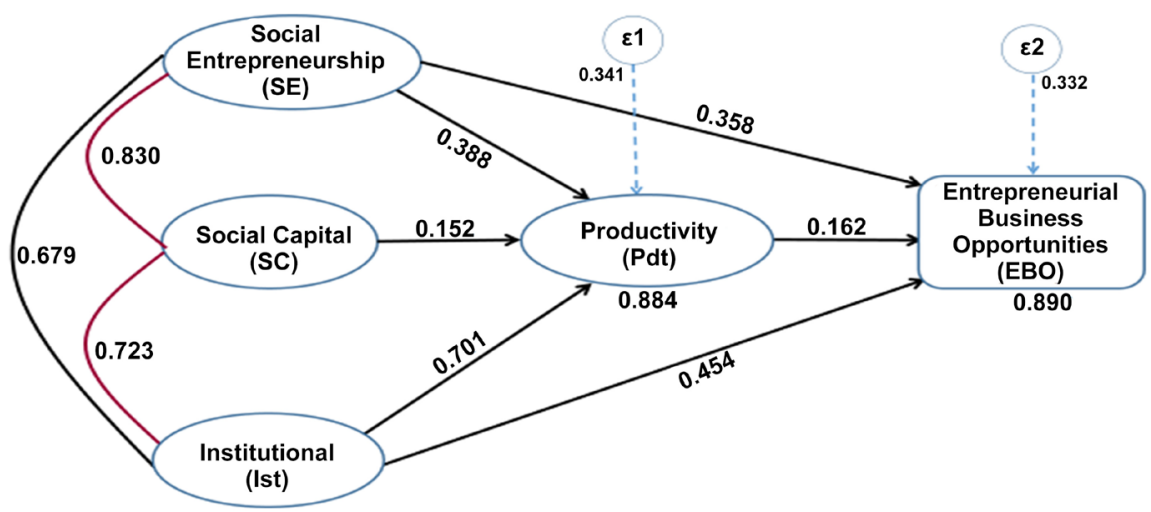

Figure 1. Description of path analysis on the role of social entrepreneurship and institutional collaboration on entrepreneurial business opportunities.

related institutions directly increase the productivity level to promote better and optimal entrepreneurial business opportunities. The contribution of social entrepreneurship and institutional roles are still the most optimal, as shown in Table 3. The "standardized coefficients beta" value of social entrepreneurship and institutional variables is still consistent. It makes the most dominant contribution to entrepreneurial business opportunities than other variables, including standardization, commercialization, inventions, new products, and technology.

The qualitative rationality research shows that social entrepreneurship activities in natural disasters, including the Covid-19 pandemic, are more inclusive. It covers all aspects of activities useful in a "social economics scope." During a disaster, social entrepreneurship activities strengthen all aspects not completed by existing institutions, both formally and informally. These activities emphasize the complementarity and collaboration between social entrepreneurship activities and related institutions to solve existing problems. The community feels safe to continue its activities for sustainable development goals. Importantly, complementarity and collaboration take place consciously, responsibly, and free from existing political pressures. This indicates that social capital's role reflected in "cooperation" and cultural aspects in the community is still high in strengthening resilience and competitiveness. However, there is a tendency for the role of social capital to decline (Prasetyo, 2019b; Prasetyo, Setyadharma, \& Kistanti, 2020b).

There is a need to fully realize that any disaster mitigation, including the impact of Covid-19, requires the quality of existing institutions, especially in the social sector, and the active participation of the whole community, such as social entrepreneurship activists. This research confirms that collaboration and complementarity between related institutions and social entrepreneurship are vital in disaster mitigation. Corruption by related institutions during the Covid-19 pandemic, especially in the social sector, is the most perfect, evil, and the craziest of all corruption acts worldwide. This is because institutions not aligned greatly hinder entrepreneurship (de la Chaux \& Haugh, 2020). In this research, there 
were indications that the higher the institution quality, the tighter and stronger the collaboration level of social entrepreneurship. Furthermore, the stronger the collaboration or causality level between the two variables, the stronger the disaster mitigation. This promotes the achievement of sustainable development locally.

Corruption in a related institution weakens quality and causality. This further worsens the condition and mitigation efforts for the development of the region. Institution committing corruption decreases the communities, enthusiasm, and happiness, making them more apathetic. Therefore, the use of existing resources is not optimal and affects its creativity, investment, invention, innovation, standardization, productivity, and economic growth of the region, and increases poverty and inequality. Even though this research remains objective, it still has weaknesses as a case study, meaning it scientifically lacks generalizability.

This research confirms that corruption in any form, institutionally or individually, is detrimental to the community. Specifically, it weakens sustainable development and reduces socio-economic equity. Several studies showed that corruption is more detrimental and hinders successful entrepreneurship and sustainable development (Borlea et al., 2017; Frolova et al., 2019; Hoinaru et al., 2020). In a morally correct rationality theory of "sand the wheels," corruption affects innovative activities and economic growth negatively. Therefore, this research does not support the finding that corruption is positively related to entrepreneurship, is considered a viable and socially acceptable strategy, and facilitates entrepreneurship (Chowdhury et al., 2019). This positive effect is also known as "grease the wheels." Some have found contradictory relationships (Hoinaru et al., 2020). Hoinaru et al.'s research (Hoinaru et al., 2020) stated that corruption positively correlates with the formation of new formal companies. However, squared corruption negatively correlates with company formation. Bologna \& Ross (2015) established that corruption is detrimental in most cities in Brazil but helps where governance is weakest.

This research has quantitatively and qualitatively described how complementization and collaboration between social entrepreneurship and institutions could optimally contribute to the "value chain" as the main driver of entrepreneurial business opportunities and sustainable regional development. Value chains are better supply sources, a more effective and efficient strategy to gain a competitive advantage (Prasetyo \& Dzaki, 2020). The NPD value chain strategy with related institutions can change the role and atmosphere of community life in the local area to be more human (Prasetyo \& Dzaki, 2020). The results of this research can be empirically and quantitatively be strengthened and re-described, as shown in Table 2 and Table 3 . These tables show that social entrepreneurship and related institutional factors have a dominant and significant contribution in promoting entrepreneurial business and sustainable regional development. The community's real social entrepreneurship activities are affected by various informal institutions, especially from entrepreneurial culture, local wisdom traditions, 
Table 2. The results of the path analysis as the main factor driving opportunities for sustainable entrepreneurship.

\begin{tabular}{|c|c|c|c|c|c|c|c|c|c|}
\hline & \multirow[t]{2}{*}{ Model } & \multicolumn{2}{|c|}{$\begin{array}{l}\text { Unstandardized } \\
\text { Coefficients }\end{array}$} & \multirow{2}{*}{$\begin{array}{c}\text { Standardized } \\
\text { Coefficients }\end{array}$} & \multirow[t]{2}{*}{ t-stc } & \multirow[t]{2}{*}{ Sig. } & \multicolumn{3}{|c|}{ Correlations } \\
\hline & & B & Std. Error & & & & Zero-order & Partial & Part \\
\hline & (Constant) & -0.075 & 0.039 & & -1.955 & 0.053 & & & \\
\hline & Social Capital (SC) & 0.294 & 0.091 & 0.256 & 3.242 & 0.002 & 0.800 & 0.284 & 0.130 \\
\hline \multirow[t]{5}{*}{ 3) } & Social Entrepreneurship (SE) & 0.200 & 0.087 & 0.184 & 2.287 & 0.024 & 0.785 & 0.204 & 0.091 \\
\hline & Institutional (Ist) & 0.450 & 0.109 & 0.348 & 4.125 & 0.000 & 0.835 & 0.352 & 0.165 \\
\hline & Productivity (Pdt) & 0.185 & 0.076 & 0.208 & 2.427 & 0.017 & 0.814 & 0.216 & 0.097 \\
\hline & (Constant) & -0.088 & 0.038 & & -2.274 & 0.025 & & & \\
\hline & Human Capital (HC) & 0.178 & 0.063 & 0.170 & 2.847 & 0.005 & 0.671 & 0.252 & 0.115 \\
\hline \multirow[t]{3}{*}{ 4) } & Social Entrepreneurship (SE) & 0.397 & 0.066 & 0.364 & 6.033 & 0.000 & 0.785 & 0.482 & 0.243 \\
\hline & Institutional (Ist) & 0.400 & 0.121 & 0.309 & 3.312 & 0.001 & 0.835 & 0.289 & 0.134 \\
\hline & Productivity (Pdt) & 0.160 & 0.076 & 0.180 & 2.105 & 0.037 & 0.814 & 0.189 & 0.085 \\
\hline
\end{tabular}

Model-3 \& model 4) Dependent Variable: Entrepreneurial Business Opportunities (EBO).

Table 3. The strength of social entrepreneurship and institutional roles in entrepreneurial business opportunities.

\begin{tabular}{|c|c|c|c|c|c|c|c|c|}
\hline & \multirow{2}{*}{ Model } & \multicolumn{2}{|c|}{ Unstandardized Coefficients } & \multirow{2}{*}{$\begin{array}{c}\begin{array}{c}\text { Standardized } \\
\text { Coefficients }\end{array} \\
\text { Beta }\end{array}$} & \multirow{2}{*}{ t-stc } & \multirow{2}{*}{ Sig. } & \multicolumn{2}{|c|}{ Collinearity Statistics } \\
\hline & & $\mathrm{B}$ & Std. Error & & & & Tolerance & VIF \\
\hline \multirow{3}{*}{ 5) } & (Constant) & -0.114 & 0.029 & & -3.914 & 0.000 & & \\
\hline & Social Entrepreneurship (SE) & 0.416 & 0.057 & 0.382 & 7.273 & 0.000 & 0.535 & 1.868 \\
\hline & Standardization (Std) & 0.245 & 0.050 & 0.267 & 4.925 & 0.000 & 0.502 & 1.991 \\
\hline \multirow{3}{*}{ 6) } & (Constant) & -0.098 & 0.032 & & -3.013 & 0.003 & & \\
\hline & Social Entrepreneurship (SE) & 0.432 & 0.059 & 0.396 & 7.262 & 0.000 & 0.539 & 1.857 \\
\hline & Institutional (Ist) & 0.499 & 0.095 & 0.386 & 5.255 & 0.000 & 0.298 & 3.354 \\
\hline \multirow{4}{*}{ 7) } & (Constant) & -0.114 & 0.033 & & -3.426 & 0.001 & & \\
\hline & Social Entrepreneurship (SE) & 0.457 & 0.061 & 0.419 & 7.441 & 0.000 & 0.533 & 1.875 \\
\hline & Institutional (Ist) & 0.548 & 0.104 & 0.424 & 5.252 & 0.000 & 0.261 & 3.836 \\
\hline & Invention (Inv) & 0.148 & 0.063 & 0.160 & 2.352 & 0.020 & 0.367 & 2.724 \\
\hline \multirow{4}{*}{ 8) } & (Constant) & -0.151 & 0.031 & & -4.915 & 0.000 & & \\
\hline & Social Entrepreneurship (SE) & 0.443 & 0.061 & 0.407 & 7.233 & 0.000 & 0.539 & 1.854 \\
\hline & Institutional (Ist) & 0.858 & 0.097 & 0.663 & 8.856 & 0.000 & 0.306 & 3.271 \\
\hline & New Product D (NP) & 0.135 & 0.065 & 0.135 & 2.085 & 0.039 & 0.407 & 2.458 \\
\hline \multirow{3}{*}{ 9) } & (Constant) & -0.108 & 0.032 & & -3.370 & 0.001 & & \\
\hline & Institutional (Ist) & 0.553 & 0.088 & 0.427 & 6.249 & 0.000 & 0.349 & 2.867 \\
\hline & Technology (Tnl) & 0.203 & 0.062 & 0.215 & 3.272 & 0.001 & 0.378 & 2.644 \\
\hline
\end{tabular}

Model-5, 6, 7, 8, \& 9) Dependent Variable: Entrepreneurial Business Opportunities (EBO). 
social capital, and social networks reflected in human capital. Table 2 quantitatively shows the results of this study.

The results in Table 2, especially model-3, strengthen the assertion that social capital in collaborating with productivity is essential in promoting the resilience of sustainable entrepreneurial business opportunities through the cultural principle of "tuna satak bathi sanak" or "tuna satak bathi kinsmen" The slight decrease in the social entrepreneurship shows that its main orientation is greater in its social mission. This research empirically found and supported previous study, which stated that there is a cultural business principle of "tuna satak bathi sanak" in entrepreneurial endeavors (Prasetyo, 2019a, 2019b). The principle is used to optimize business resources for survival and a competitive strategy, which in the short term has a greater social than economic orientation. The long-term vision is to achieve a sustainable increase in the competitiveness of entrepreneurial ventures. This means that this research supports the basic theory of entrepreneurship from Schumpeter, which states that entrepreneurs should innovate, collect resources and utilize them optimally (Schumpeter, 1949). Furthermore, the results in model-4 are in line with the research, which states that to produce value, social entrepreneurship requires a different configuration of human resources from commercial entrepreneurship (Acs et al., 2018).

The cultural business principle of "tuna satak bathi kinsmen" as an effort to optimize the use of these resources shows creative innovation. In its development, these innovations can create "social value creation" as a socio-economic "value chain" in promoting and strengthening resilience and security for sustainable development goals. Improving institutional performance and "value chains" with new product development improves entrepreneurial competitive advantage (Prasetyo \& Dzaki, 2020). This shows that social entrepreneurship is unique and more complex than economic entrepreneurship. During a crisis, the problem gets bigger and more complex, especially when faced with the option to maximize profits or social value. This study also supports the previous research, which showed that social entrepreneurship functions as product innovation, social capital, standardization, new business opportunities, social business models, an effort to boost regional development and increase productivity (Aponte, Alvarez, \& Lobato, 2019; Arendt \& Grabowski, 2020; Doh, 2020; Kim et al., 2020; Hatak \& Zhou, 2021). Aponte, Alvarez, \& Lobato (2019) examined the relationship between social entrepreneurship activities and sustainable regional economic development in a country.

According to Fuchsová, Laštovková, \& Jánská (2019), the low attractiveness of regions for foreign direct investment weakens business activities and stimulates social entrepreneurship growth, though not proven. This research confirms that the low attractiveness of foreign direct investment regions is attributed to low regional infrastructure. However, the high attractiveness is due to the low incentive for labor wages. This means that the increase in social entrepreneurial activities regionally is not due to low foreign direct investment. However, the emer- 
gence of social entrepreneurship is attributed to low wages, which encourage workers to open their own entrepreneurial businesses independently and jointly in partnership, including social entrepreneurship.

Fuentelsaz, González, \& Maicas (2019) stated that formal institutions defined as efficient institutional architecture are not entirely correct. This is because the role of informal institutions through social capital is efficient. Furthermore, the standardization of inventions and technology drives the use of resources to be more efficient. This research found that social capital's role further strengthens the social identity of entrepreneurs, especially at the beginning of the social entrepreneurship business model. Combining the collaboration role with other aspects (as in Table 3) identifies more optimal, effective, and efficient collaboration in supporting sustainable entrepreneurial business opportunities. This research is in line with Sohel (2018), which identified challenges and developed an institutional framework model to promote successful, positive, systematic, and sustainable social entrepreneurship.

There are many aspects supporting the creation of entrepreneurial business opportunities, apart from those in Table 3. Linearly, entrepreneurial business opportunities are heavily affected by the institutional context (Goel \& Karri, 2020). The issue of institutional inconsistency offers an interesting context for exploring entrepreneurship (Goel \& Karri, 2020). Linearly, these institutional factors have driven entrepreneurial opportunities to achieve higher levels of economic growth. However, this research examined the dynamics and collaboration between social entrepreneurship and existing institutions. The results showed that the collaboration and complementary model could optimize the use of resources. Therefore, these two main factors still have a large impact on the emergence of entrepreneurial business opportunities and sustainable regional development. Quantitatively, this statement is supported by the results in Table 3 , which describes the consistent strength of social entrepreneurship and institutional roles in entrepreneurial business opportunities as a reflection of sustainable regional development.

The argument postulated is based on previous research, which showed that social entrepreneurship is a sign and symbol of business and entrepreneurship success, apart from being a pioneer of successful business in the community (Oskooii \& Ajali, 2017). Entrepreneurial function is a revolution needed by the community, which is also considered to be more than just an industrial revolution (Oskooii \& Ajali, 2017). The novelty of this research is the role of local cultural wisdom of "tuna satak bathi kinsmen" and other local informal institutions in strengthening the social entrepreneurship collaboration with institutions to create entrepreneurial business opportunities and support sustainable regional development. The research confirms that good institutional quality without corruption further strengthens this new model of collaboration in maintaining sustainable regional business and development. Conversely, low institutional quality makes entrepreneurial business activities unproductive, inefficient, and 
ineffective. This problem affects business conditions that are not conducive and reduces the security of sustainable regional development.

\section{Conclusions, Limitations, and Further Research}

Social entrepreneurship initially existed as a source of humanist social-economic equity outside the existing basic economic structure. This was because of the individuals' invention and creativity in the community to help close the gaps that cannot be solved by public and private institutional policies. The presence of institutions further strengthens entrepreneurial business opportunity creation in the community and regional development. Furthermore, the role of social entrepreneurship collaboration and complementary with institutions is a new model of innovation that optimizes existing resources to improve productivity, entrepreneurial business opportunities, and security for sustainable regional development.

This study contributes empirically and theoretically to social entrepreneurship and institutions. The results showed that social entrepreneurship collaboration and institutional quality could be vital elements in the social innovation sustainability theory to strengthen entrepreneurship theory and new economic institutions. The new model innovation is an essential source of social-economic equity for the community. Furthermore, it can optimize the use of resources, overcome socio-economic problems and poverty, increase productivity, be a value chain that further strengthens the mechanism in promoting public and private institutional policy implementation, and mitigating security in achieving the goals of sustainable regional development.

Second, the results complement previous research that emphasized the important relationship between entrepreneurship, institutions, and economic development. Furthermore, this research emphasizes the causality relationship between entrepreneurship and institutions, as well as their roles and functions in creating productivity to achieve sustainable development security. However, the research does not distinguish between formal and informal institutional roles, only emphasizing institutional quality. A good institution with quality and corruption-free is critical in promoting sustainable entrepreneurial business opportunities.

This research has limitations as a local case study in two provinces in Indonesia. Scientifically, it cannot be directly used to generalize findings nationally and internationally. This is because the research's generalization is subject to certain limitations that can become a basis for further research. To strengthen and support these findings, other potential control variables have been used quantitatively apart from productivity. These include social capital, human capital, standardization, commercialization, inventions, new products, and technology. The potential control variable in terms of quality explores institutional variables from the formal, informal, and the institutional quality aspect. Furthermore, this research concluded that institutional quality is largely affected by the value of local 
wisdom, entrepreneurial culture, cooperation, social capital, interaction, networks, and cohesion, and lack of corruption. In general, corruption is a negative indicator that is evil and damages institutional trust, and weakens social entrepreneurship's spirit.

Entrepreneurship and institutions are important drivers of economic development with their collaboration being an effective approach. However, the collaboration is still local and not widely believed, some considering the collaboration concept to be overlapping (Schaltegger, Beckmann, \& Hockerts, 2018). The collaboration between social entrepreneurship and this institution is multi-complex and dynamic. Future study should further expand this research nationally and internationally and focus more on the role of institutional quality and the corruption impact on sustainable development. The problem of collaborative dynamics in social entrepreneurship was studied by de Bruin, Shaw, \& Lewis (2017). The research recommended that future research pay more attention to the interaction of various contexts using mixed methods to advance social entrepreneurship theory significantly.

\section{Acknowledgements}

The researcher would like to thank the Directorate General of Higher Education DRPM, Directorate of the Ministry of Education, Culture and Research and Technology of the Republic of Indonesia. Because this research is supported by funding based on the main and derivative contracts: DRPM: 044/SP2H/LT/ DRPM/2021 and SPPK Capacity: 044/E4.1/AK.04.PT/2021.

\section{Conflicts of Interest}

1) The author is responsible and states; there is no potential conflict of interest of any kind in connection with this research, either before and after its implementation, and/or publication of this article.

2) The author guarantees that this article is the original work of the author himself that has not been published, and at this time it is only sent for publication in the journal Entrepreneurship: Theory and Practice. As part of this process, this article is not being submitted and is being considered for publication elsewhere.

\section{References}

Abhi, S. (2017). Can Social Entrepreneurs Do Well By Doing Good? Blending Social and Economic Value Creation-An Investigation. Academy of Entrepreneurship Journal, 23, 1-21.

Acemoglu, D., \& Robinson, J. (2008). The Role of Institutions in Growth and Development. Working Paper, No. 10, The World Bank.

Acs, Z. J., \& Lappi, E. (2021). Entrepreneurship, Culture, and the Epigenetic Revolution: A Research Note. Small Business Economics, 56, 1287-1307. https://doi.org/10.1007/s11187-019-00230-0 
Acs, Z. J., Audretsch, D. B., Braunerhjelm, P., \& Carlsson, B. (2006). The Knowledge Spillover Theory of Entrepreneurship. Electronic Working Paper Series, 77.

Acs, Z. J., Estrin, S., Mickiewiczs, T., \& Szerb, L. (2018). Entrepreneurship, Institutional Economics and Economic Growth: An Ecosystem Perspective. Small Business Economics, 51, 501-514. https://doi.org/10.1007/s11187-018-0013-9

Agrawal, A., \& Hockerts, K. (2016). Institutional Theory as a Framework for Practitioners of Social Entrepreneurship. In T. Osburg, \&R. Schmidpeter (Eds.), Social Innovation (pp. 119-129). Springer. https://doi.org/10.1007/978-3-642-36540-9 11

Anderson, A. R., \& Gaddefors, J. (2016). Entrepreneurship as a Community Phenomenon; Reconnecting Meanings and Place. International Journal Entrepreneurship and Small Business, 28, 504-518. https://doi.org/10.1504/IJESB.2016.077576

Anderson, A. R., \& Ronteau, S. (2017). Towards an Entrepreneurial Theory of Practice; Emerging Ideas for Emerging Economies. Journal of Entrepreneurship in Emerging Economic, 9, 110-112. https://doi.org/10.1108/JEEE-12-2016-0054

Anderson, A. R., Sarah, D., \& Sarah, J. (2020). Let Them Not Make Me a Stone. A Critical Philosophy of Qualitative Entrepreneurship Scholarship. Journal of Small Business Management, in press.

Aparicio S., Turro, A., \& Noguera, M. (2020). Entrepreneurship and Intrapreneurship in Social, Sustainable, and Economic Development: Opportunities and Challenges for Future Research. Sustainability, 12, 8958. https://doi.org/10.3390/su12218958

Aparicio, S., Urbano, D., \& Gomez, D. (2018). Entrepreneurship and Regional Economic Growth in Antioquia: An Empirical Analysis. Economics and Business Letters, 7, 84-91. https://doi.org/10.17811/ebl.7.2.2018.84-92

Aponte, M., Alvarez, M., \& Lobato, M. (2019). Social Entrepreneurship and Economic Development: A Macro-Level Perspective. Journal Social Business, 9, 141-156. https://doi.org/10.1362/204440819X15504844628128

Apostolopoulos, N., Al-Dajani, H., Holt, D., Jones, P., \& Newbery, R. (2018). Entrepreneurship and the Sustainable Development Goals. In N. Apostolopoulos et al. (Eds.), Entrepreneurship and the Sustainable Development Goals (Vol. 8, pp. 1-7). Emerald Publishing Limited. https://doi.org/10.1108/S2040-724620180000008005

Arendt, L., \& Grabowski, W. (2020). The Role of Firm-Level Factors and Regional Innovation Capabilities for Polish SMEs. Journal of Entrepreneurship, Management and Innovation, 15, 11-44. https://doi.org/10.7341/20191531

Audretsch, D. B., \& Keilbach, M. (2007). The Theory of Knowledge Spillover Entrepreneurship. Journal of Management Studies, 44, 1242-1254. https://doi.org/10.1111/j.1467-6486.2007.00722.x

Bansal, S., Garg, I., \& Sharma, G. D. (2019). Social Entrepreneurship as a Path for Social Change and Driver of Sustainable Development: A Systematic Review and Research Agenda. Sustainability, 11, 1091. https://doi.org/10.3390/su11041091

Baumol, W. J. (1990). Entrepreneurship, Productive, Unproductive, and Destructive. Journal of Political Economy, 98, 893-921. https://doi.org/10.1086/261712

Baumol, W. J. (1993). The Entrepreneur in Economic Theory. In Entrepreneurship, Management, and the Structure of Payoffs. MIT Press.

Beckmann, M. (2012). The Impact of Social Entrepreneurship on Societies. In C. Volkmann, K. Tokarski, \& K. Ernst (Eds.), Social Entrepreneurship and Social Business (pp. 235-254). Gabler Verlag. https://doi.org/10.1007/978-3-8349-7093-0 12

Bencheva, N., Stoeva, T., Terziev, V., Tepavicharova, M., \& Arabska, E. (2017). The Role 
of Social Entrepreneurship for Rural Development. Journal Agricultural Sciences, 9, 89-98.

Bl'anda, J., \& Urbančíková, N. (2020). Social Entrepreneurship as a Tool of Sustainable Development. Quality Innovation Prosperity/Kvalita Inovácia Prosperita, 24, 21-36. https://doi.org/10.12776/qip.v24i3.1463

Blagoycheva, H. (2019). Social Enterprises Position in Regional Sustainable Development. Trakia Journal of Sciences, 17, 488-495. https://doi.org/10.15547/tjs.2019.s.01.079

Bologna, J., \& Ross, A. (2015). Corruption and Entrepreneurship: Evidence from Brazilian Municipalities. Public Choice, 165, 59-77. https://doi.org/10.1007/s11127-015-0292-5

Borlea, S. N., Achim, M. V., \& Miron, M. G. (2017). Corruption, Shadow Economy and Economic Growth: An Empirical Survey across the European Union Countries. Studia Universitatis and Economics Series, 27, 19-32. https://doi.org/10.1515/sues-2017-0006

Bruton, G. D., Alhstrom, D., \& Li, H. L. (2010). Institutional Theory and Entrepreneurship: Where Are We Now and Where Do We Need to Move in the Future? Entrepreneurship Theory and Practice, 5, 421-440.

https://doi.org/10.1111/j.1540-6520.2010.00390.x

Callavo, T. (2018). Unpacking Social Entrepreneurship: Exploring the Definition Chaos and Its Consequences in England. Journal of Entrepreneurship, Management and Innovation, 14, 49-82. https://doi.org/10.7341/20181423

Chowdhury, F., David, B., Audretsch, \& Belitski, M. (2019). Entrepreneurship Quality. Entrepreneurship Theory and Practice, 43, 51-81. https://doi.org/10.1177/1042258718780431

de Bruin, A., Shaw, E., \& Lewis, K. V. (2017). The Collaborative Dynamic in Social Entrepreneurship. Entrepreneurship \& Regional Development, 29, 575-585. https://doi.org/10.1080/08985626.2017.1328902

de la Chaux, M., \& Haugh, H. (2020). When Formal Institutions Impede Entrepreneurship: How and Why Refugees Establish New Ventures in the Dadaab Refugee Camps. Entrepreneurship \& Regional Development, 32, 827-851. https://doi.org/10.1080/08985626.2020.1789752

Deng, W., Liang, Q., Fan, P., \& Cui, L. (2020). Social Entrepreneurship and Well-Being: The Configurational Impact of Institutions and Social Capital. Asia Pacific Journal of Management, 37, 1013-1037. https://doi.org/10.1007/s10490-019-09660-6

Doh, S. (2020). Social Entrepreneurship and Regional Economic Development: The Case of Social Enterprise in South Korea. Sustainability, 12, 8843. https://doi.org/10.3390/su12218843

Fàbregues, S., Hong, Q. N., Barrios, E. L. E, Guetterman, T. C. Meneses, J., \& Fetters, M. D. (2020). A Methodological Review of Mixed Methods Research in Palliative and End-of-Life Care (2014-2019). International Journal of Environmental Research and Public Health, 17, 3853. https://doi.org/10.3390/ijerph17113853

Farny, S., \& Binder, J. (2021). Sustainable Entrepreneurship. In L. P Dana (Eds.), World Encyclopedia of Entrepreneurship (pp. 605-611). Edward Elgar Publishing. https://doi.org/10.4337/9781839104145.00076

Farny. S., Kibler, E., \& Down, S. (2019). Collective Emotions in Institutional Creation Work. Academy of Management Journal, 62, 765-799. https://doi.org/10.5465/amj.2016.0711

Farouq, T., \& Dadwal, S. (2019). The Impact of Entrepreneurship on Economic Growth 
and Development in the UK. International Journal of Entrepreneurship Management Innovation and Development, 2, 116-146.

Frolova, I., Voronkova, O., Alekhina, N., Kovaleva, I., Prodanova, N., \& Kashirskaya, L. (2019). Corruption as an Obstacle to Sustainable Development: A Regional Example. Entrepreneurship and Sustainability Issues, 7, 674-689. https://doi.org/10.9770/jesi.2019.7.1(48)

Fuchsová, E., Laštovková, J., \& Jánská, M. (2019). Social Capital and Entrepreneurship in a Regional Context. Acc Journal, 25, 46-54. https://doi.org/10.15240/tul/004/2019-2-003

Fuentelsaz, L., González, C., \& Maicas, J. P. (2019). Formal Institutions and Opportunity Entrepreneurship. The Contingent Role of Informal Institutions. BRQ Business Research Quarterly, 22, 5-24. https://doi.org/10.1016/j.brq.2018.06.002

Goel, S., \& Karri, R. (2020). Entrepreneurial Aspirations and Poverty Reduction: The Role of Institutional Context. Entrepreneurship \& Regional Development, 32, 91-111. https://doi.org/10.1080/08985626.2019.1640484

Guo, B., Jin, X., Fang, Y., \& Zhou, Y. (2020). Evaluation of Sustainable Regional Development Combining Remote Sensing Data and Ecological Constraints. Sustainability, 12, 9836. https://doi.org/10.3390/su12239836

Hatak, I., \& Zhou, H. (2021). Health as Human Capital in Entrepreneurship: Individual, Extension, and Substitution Effects on Entrepreneurial Success. Entrepreneurship Theory and Practice, 45, 18-42. https://doi.org/10.1177/1042258719867559

Hoinaru, R., Buda, D., Borlea, S. N., \& Achim, M. V. (2020). The Impact of Corruption and Shadow Economy on the Economic and Sustainable Development. Do They "Sand the Wheels" or “Grease the Wheels?” Sustainability, 12, 481. https://doi.org/10.3390/su12020481

Hosseini, S. A., \& Ziaaldini, M. (2019). Social Entrepreneurship and Sustainable Development. International Journal of Business Management, 4, 52-59. https://www.sciarena.com

Jilenga, M. T. (2017). Social Enterprise and Economic Growth: A Theoretical Approach and Policy Recommendations. International Journal of Academic Research in Accounting, Finance and Management Sciences, 7, 41-49. https://doi.org/10.6007/IJARAFMS/v7-i1/2538

Jovovic, R., Draskovic, M., Delibasic, M., \& Jovovic, M. (2017). The Concept of Sustainable Regional Development-Institutional Aspects, Policies and Prospects. Journal of International Studies, 10, 255-266. https://doi.org/10.14254/2071-8330.2017/10-1/18

Kazmi, S. A., Hashim, M., Hung, D. M., \& Khan, F. U. (2016). Social Entrepreneurship and its Impact on Economy: In Perspective of Pakistan. International Journal of Academic Research in Accounting, Finance and Management Sciences, 6, 161-166.

Khovrak, I. (2018). Social Entrepreneurship and Its Role in Sustainable Development: Regulation, Funding and Trust Building. Studia i Materiaïy, 1, 22-33.

https://doi.org/10.7172/1733-9758.2018.27.2

Kibler, E., \& Muñoz, P. (2020). Social Entrepreneurship in Context and as Practice. Regional Studies, 54, 1317-1319. https://doi.org/10.1080/00343404.2020.1758447

Kim, M. G., Lee, J. H., Roh, T., \& Son, H. (2020). Social Entrepreneurship Education as an Innovation Hub for Building an Entrepreneurial Ecosystem: The Case of the KAIST Social Entrepreneurship. Sustainability, 12, 9736. https://doi.org/10.3390/su12229736

Kimmitt, J., \& Muñoz, P. (2018). Sensemaking the "Social” in Social Entrepreneurship. 
International Small Business Journal, 36, 859-886. https://doi.org/10.1177/0266242618789230

Kraus, S., Halbertstadt, J., Niemand, T., Shaw, E., \& Syrja, P. (2017). Social Entrepreneurship Orientation: Development of a Measurement Scale. International Journal of Entrepreneurial Behavior \& Research, 23, 977-997. https://doi.org/10.1108/IJEBR-07-2016-0206

Lee, C. K., Simmons, S. A., Amezcua, A., Lee, J. Y., \& Lumpkine, G. T. (2020). Moderating Effects of Informal Institutions on Social Entrepreneurship Activity. Journal of Social Entrepreneurship. https://doi.org/10.1080/19420676.2020.1782972

Leoutre, J., Justo, R., Terjesen, S., \& Bosma, N. (2020). Designing a Global Standardized Methodology for Measuring Social Entrepreneurship Activity: The Global Entrepreneurship Monitor Social Entrepreneurship Study. Small Business Economic, 2013, 693-714. https://doi.org/10.1007/s11187-011-9398-4

Mehmood, T., Alzoubi, H. M., Al-Gasaymeh, A., \& Ahmed, G. (2019). Schumpeterian Entrepreneurship Theory: Evolution and Relevance. Academy of Entrepreneurship Journal, 25, 1-10.

Méndez-Picazo, M.-T., Galindo-Martín, M. A., \& Castaño-Martínez, M.-S. (2021). Effects of Sociocultural and Economic Factors on Social Entrepreneurship and Sustainable Development. Journal of Innovation \& Knowledge, 6, 69-77. https://doi.org/10.1016/j.jik.2020.06.001

Muñoz, P., \& Kibler, E. (2017). Institutional Complexity and Social Entrepreneurship: A Fuzzy-Set Approach. Journal of Business Research, 69, 1314-1318. https://doi.org/10.1016/j.jbusres.2015.10.098

Neumann, T. (2021). The Impact of Entrepreneurship on Economic, Social and Environmental Welfare and Its Determinants: A Systematic Review. Management Review Quarterly, 71, 553-584.

Nicholls, A. (2018). Social Entrepreneurship: New Models of Sustainable Social Change. Oxford University Press.

North, D. C. (1990). Institutions, Institutional Change and Economic performance. Cambridge University Press. https://doi.org/10.1017/CBO9780511808678

North, D. C. (2003). The Role of Institutions in Economic Development. UNECE Discussion Paper Series No. 2003.2.

North, D. C. (2006). Understanding the Process of Economic Change. Princeton University Press.

North, D. C. (2016). Institutions and Economic Theory. The American Economist, 61, 72-76. https://doi.org/10.1177/0569434516630194

OECD (2017). Strengthening Women's Entrepreneurship in ASEAN “Towards Increasing Women's Participation in Economic Activity. COPAS by Canada.

https://www.oecd.org/southeast-asia

Ogbo, A., Igwe, A., Ezeobi, J., Modebe, N., \& Ume, K. E. (2019). The Impact of Social Entrepreneurship on the Sustainability of Selected Small and Medium Enterprises in Nigeria. Advances in Research, 19, 1-15. https://doi.org/10.9734/air/2019/v19i230116

Oskooii, N., \& Ajali, J. (2017). Social Capital and Social Entrepreneurship and Innovation Culture. Innovative Marketing, 13, 42-46. https://doi.org/10.21511/im.13(3).2017.05

Pongracz, E. (2020). Social Economy and Social Entrepreneurship-The Manifestation of Social Responsibility in the Era of Globalization. The 19th International Scientific Conference Globalization and Its Socio-Economic Consequences 2019-Sustainability 
in the Global-Knowledge Economy, 74, 1-6. https://doi.org/10.1051/shsconf/20207404021

Popov, E. V., Veretennikova, A. Y., \& Kozinskaya, K. M. (2018). Formal Institutional Environment Influence on Social Entrepreneurship in Developed Countries. Montenegrin Journal of Economics, 14, 45-56. https://doi.org/10.14254/1800-5845/2018.14-4.3

Porter, M. E., \& Heppelemann, J. E. (2017). Why Every Organization Needs an Augmented Reality Strategy. Harvard Business Review, 95, 46-57. https://www.harvardbusiness.org

Prasetyo, P. E. (2019a). The Reliability of Entrepreneurial Productivity as Driver of Economic Growth and Employment. International Journal of Entrepreneurship, 23, 1-15.

Prasetyo, P. E. (2019b). International Journal of Economics and Financial Issues. International Journal of Economics and Financial Issues, 9, 237-243. https://doi.org/10.32479/ijefi.7882

Prasetyo, P. E. (2020a). The Role of Government Expenditure and Investment for MSME Growth: Empirical Study in Indonesia. Journal of Asian Finance, Economics and Business, 7, 471-480. https://doi.org/10.13106/jafeb.2020.vol7.no10.471

Prasetyo, P. E. (2020b). Human Capital as the Main Determinant of Regional Economic Growth. International Journal of Advanced Science and Technology, 29, 6261-6267.

Prasetyo, P. E., \& Dzaki, F. Z. (2020). Institutional Performance and New Product Development Value Chain for Entrepreneurial Competitive Advantage. Uncertain Supply Chain Management, 8, 753-760. https://doi.org/10.5267/j.uscm.2020.7.004

Prasetyo, P. E., \& Kistanti, N. R. (2020a). Human Capital, Institutional Economics and Entrepreneurship as a Driver for Quality \& Sustainable Economic Growth. Entrepreneurship and Sustainability Issues, 7, 2575-2589.

https://doi.org/10.9770/jesi.2020.7.4(1)

Prasetyo, P. E., \& Kistanti, N. R. (2020b). Role of Social Entrepreneurship in Supporting Business Opportunities and Entrepreneurship Competitiveness. Open Journal of Business and Management, Scientific Research, 8, 1412-1425.

https://doi.org/10.4236/ojbm.2020.84090

Prasetyo, P. E., Setyadharma, A., \& Kistanti, N. R. (2019). The Relationship between Institutions and Business Opportunities toward Economic Growth. Economics Development Analysis Journal, 8, 281-291. https://doi.org/10.15294/edaj.v8i4.36311

Prasetyo, P. E., Setyadharma, A., \& Kistanti, N. R. (2020a). The Role of Social Capital in New Products Development and Business Competitiveness Enhancement. International Journal of Scientific \& Technology Research, 9, 1838-1843.

Prasetyo, P. E., Setyadharma, A., \& Kistanti, N. R. (2020b). Social Capital: The Main Determinant of MSME Entrepreneurship Competitiveness. International Journal of Scientific \& Technology Research, 9, 6627-6637.

Restrepo, N., \& Clave, S. A. (2019). Institutional Thickness and Regional Tourism Development: Lessons from Antioquia, Colombia. Sustainability, 11, 2568. https://doi.org/10.3390/su11092568

Roundy, P. T., \& Bonnal, M. (2019). Social Entrepreneurship and Economic Thought: A Synthesis and Path to Rapprochement. Global Business and Economics Review, 23, 257-279. https://doi.org/10.1504/GBER.2020.110014

Royle, M. T., \& Hall, A. T. (2012). The Relationship between Mcclelland's Theory of Needs, Feeling Individually Accountable, and Informal Accountability for Others. International Journal of Management and Marketing Research, 5, 21-42. 
Saebi, T., Foss, N. J., \& Linder, S. (2019). Social Entrepreneurship Research: Past Achievements and Future Promises. Journal of Management, 45, 70-95. https://doi.org/10.1177/0149206318793196

Samadi, A. H. (2019). Institutions and Entrepreneurship: Unidirectional or Bidirectional Causality? Journal of Global Entrepreneurship Research, 9, Article No. 3. https://doi.org/10.1186/s40497-018-0129-z

Sanchez, J. D. C. (2018). Institutional Strength, Peacebuilding, and Productive Entrepreneurship-Exploratory Analysis in Colombia. Business: Theory and Practice, 19, 88-102. https://doi.org/10.3846/btp.2018.10

Santos, F. M. (2010). A Theory of Social Entrepreneurship. International Conference on Technology Policy and Innovation, 13-14, 1-19. https://www.insead.edu/se

Sarango-Lalangui, P. S., Santos, J. L. S., \& Hormiga, E. (2018). The Development of Sustainable Entrepreneurship Research Field. Sustainability, 10, 2005.

Schaltegger, S., Beckmann, M., \& Hockerts, K. (2018). Sustainable Entrepreneurship: Creating Environmental Solutions in Light of Planetary Boundaries. International Journal Entrepreneurial Venturing, 10, 1-16. https://doi.org/10.1504/IJEV.2018.090990

Schumpeter, J. A. (1942). Capitalism, Socialism, and Democracy (p. 381). Harper \& Bros. https://doi.org/10.2307/2226398

Schumpeter, J. A. (1949). Economic Theory and Entrepreneurial History in Change and the Entrepreneur. Research Center in Entrepreneurial History, Harvard University Press.

Seelos, C., \& Mair, J. (2009). Hope for Sustainable Development: How Social Entrepreneurs Make It Happen. In R. Ziegler (Ed.), An Introduction to Social Entrepreneurship: Voices, Preconditions and Contexts (pp. 228-245). Edward Elgar.

Sohel, M. H. (2018). Developing Institutional Framework of Social Entrepreneurship. Thesis, Faculty of Management, Universiti Teknologi Malaysia.

Starnawska, M., \& Brzozowska, A. (2018). Social Entrepreneurship and Social Enterprise Phenomenon: Antecedents, Processes, Impact across Cultures and Contexts. Journal of Entrepreneurship, Management and Innovation, 14, 3-18. https://doi.org/10.7341/20181421

Stephan, U., Uhlaner, L. M., \& Stride, C. (2015). Institutions and Social Entrepreneurship: The Role of Institutional Voids, Institutional Support, and Institutional Configurations. Journal of International Business Studies, 46, 308-331. https://doi.org/10.1057/jibs.2014.38

Steyart, C., \& Hjorth, D. (2006). Entrepreneurship as Social Change. Edward Elgar. https://doi.org/10.4337/9781847204424

Tan, W. L., Williams, J., \& Tan, T. M. (2005). Defining the "Social" in "Social Entrepreneurship": Altruism and Entrepreneurship. International Entrepreneurship and Management Journal, 1, 353-365. https://doi.org/10.1007/s11365-005-2600-X

Turok, I., \& Alexis, H. (2020). Territorial Collaboration: A Novel Way to Spread Prosperity. Regional Studies, 54, 1776-1786. https://doi.org/10.1080/00343404.2020.1807490

Tvaronavičienė, M., \& Lankauskienè, T. (2012). Security and Sustainable Development: Approaches and Dimensions in the Globalization Context. Journal of Security \& Sustainability Issues, 1, 287-297.

Volkmann, C., Fichter, K., Klofsten, M., \& Audretsch, D. B. (2021). Sustainable Entrepreneurial Ecosystems: An Emerging Field of Research. Small Business Economics, 56, 1047-1055. https://doi.org/10.1007/s11187-019-00253-7 
Wiklund, J, Eliasson, C., \& Davidsson, P. (2002). Entrepreneurial Management and Schumpeterian Resource Recombination. Paper presented at the 21st Babson Entrepreneurship Research Conference, Boulder, June 2002, 1-16.

Williamson, O. E. (2000). The New Institutional Economics: Taking Stock, Looking Ahead. Journal of Economic Literature, 38, 595-613.

Zaki, R. M. R. (2018). An Overview of Social Entrepreneurship. AUC Research Conference, Entrepreneurship \& Innovation: Shaping the Future of Egypt, Egypt. 